\title{
Peran Sukuk Terhadap Pembangunan Infrastruktur
}

\author{
Maula Robin Haq \\ IAIN KUDUS \\ Jl. Conge Ngembalrejo Bae Kudus \\ robinhaq7@gmail.com \\ Diah Putri Febiana Sari \\ IAIN KUDUS \\ Jl. Conge Ngembalrejo Bae Kudus \\ diahput69@gmail.com \\ Kharis Fadhullah Hana \\ IAIN KUDUS \\ Jl. Conge Ngembalrejo Bae Kudus \\ kharis@iainkudus.ac.id
}

\begin{abstract}
Abstrak
Pembangunan infrastruktur dengan sukuk saat ini tengah berkembang pesat. Sukuk merupakan obligasi yang berdasarkan prinsip islam. Sukuk memiliki tingkat pengembalian dana yang lebih rendah dibandingkan dengan obligasi yang berbasis bunga. Penelitian ini bertujuan memberikan penjelasan mengenai peran sukuk terhadap pembangunan infrastruktur di indonesia. Penelitian ini menggunakan metode kualitatif yang dianalisa secara deskriptif. Dengan data sekunder yang berasal dari literature review berupa hasil penelitian sebelumnya, dokumen dari lembaga atau instasi yang valid, news, serta sumber lain yang mendukung. Hasilnya menunjukkan bahwa Sukuk menjadi instrumen keuangan yang penting diterapkan dalam pembangunan infrastruktur dan memiliki kontribusi positif dalam
\end{abstract}


pembangunan infrastruktur. Sejak diterbitkan sampai tanggal 13 Februari 2020, Akumulasi hasil penerbitan SBSN sudah mencapai Rp. 1.253,4 T. Hasil penerbitan Sukuk tersebut digunakan pemerintah untuk membiayai berbagai proyek infrastruktur di Indonesia. Jadi Pemerintah bisa memaksimalkan potensi sukuk sebagai alternatif pembiayaan infrastruktur dan mulai mengurangi ketergantungan pada hutang luar negeri dalam pembiayaan infrastruktur.

\section{Abstract}

Infrastructure development with Sukuk is currently developing rapidly. Sukuk are bonds based on Islamic principles. Sukuk have lower refund rates compared to interest-based bonds. This study aims to explain the role of Sukuk in infrastructure development in Indonesia. This research uses qualitative methods that are analyzed descriptively. With secondary data derived from the literature review in the form of the results of previous studies, documents from valid institutions or institutions, news, and other supporting sources. The results show that Sukuk is an important financial instrument applied in infrastructure development and has a positive contribution to infrastructure development. Since it was published until February 13, 2020, the accumulation of SBSN issuance results has reached $\mathrm{Rp} .1,253.4 \mathrm{~T}$. The results of the issuance of the Sukuk were used by the government to finance various infrastructure projects in Indonesia. So the Government can maximize the potential of Sukuk as an alternative to infrastructure financing and start reducing dependence on foreign debt in infrastructure financing.

\section{Kata kunci: Sukuk, Pembangunan Infrastruktur, Keuangan Syariah}

Keywords: Sukuk, Infrastructure Development, Islamic Finance 


\section{A. PENDAHULUAN.}

\section{Latar Belakang}

Infrastruktur merupakan bagian penting pada suatu negara untuk mendukung pertumbuhan dan perkembangan ekonomi. Infrastruktur yang tidak memadai, akan menghambat kemajuan dan kompetisi negara dibanding negara lainnya. ${ }^{1}$ Salah satu masalah dalam pengadaan infrastruktur adalah ketersediaan anggaran pembiayaan dalam rangka pemenuhan kebutuhan infrastruktur yang sangat terbatas, sehingga terjadi celah pembiayaan infrastruktur (infrastructure gap) ${ }^{2}$. untuk menutupi kekurangan dana, pemerintah harus bisa mencari sumber dana alternatif pembangunan infrastruktur selain APBN, yaitu dengan cara menerbitkan Surat Utang Negara (SUN) dan pinjaman dari luar Negeri dalam bentuk utang, baik dari negara-negara lain (Jerman, Amerika Serikat, Jepang dan lainnya) atau pinjaman dari Lembaga Keuangan Internasional (IDB, ADB, IMF, World Bank dan Sebagainya) ${ }^{3}$.

Sayangnya, saat pemerintah menerbitkan SUN tidak lepas dari beban bunga yang besar yang ditawarkan kepada investor sehingga menjadi beban negara dalam APBN untuk membayar bunganya. Belum lagi jika sumber dana dari pinjaman dari luar negeri yang sangat merugikan negara, karena mengunakan sistem bunga. sehingga diperlukan alternatif baru sebagai sumber pendanaan infrastruktur yaitu dengan menerbitkan Sukuk ${ }^{4}$. Sebagaimana yang tertuang dalam

1 Fauziah and Nurwahidin, "Pembiayaan Infrastruktur Dengan Sukuk Negara Di Indonesia: Prosedur Dan Struktur."

${ }^{2}$ Adi, "Analisis Surat Berharga Syariah Negara (SBSN)/Sukuk Dalam Upaya Mendukung Skema Pembiayaan Infrastruktur Di Indonesia."

3 Fadian, "Analisis Peran Sukuk Bagi Pembangunan Infrastruktur Di Indonesia."

${ }^{4}$ Helmi, "Komparasi Pembiayan Pembangunan Infrastruktur Pemerintah Dengan Dana Obligasi Konvensional Dan Obligasi Syariah / Sukuk (Studi Kasus Pembangunan Jalan Tol Trans Sumatera)." 
Undang-Undang Nomor 19 Tahun 2008 tentang Surat Berharga Syariah Negara (SBSN), pembiayaan melalui sukuk tepat digunakan untuk pembiayaan infrastruktur. Dikarenakan Sukuk memegang prinsip yang sesuai dengan syariat islam sehingga terhindar dari hal-hal yang diharamkan. Seperti mengandung unsur riba, gharar, maisir dan lain- lain ${ }^{5}$.

Penelitian ini berusaha untuk mengetahui lebih lanjut mengenai prospek pemanfaatan sukuk guna mendorong pembangunan infrastruktur serta sukuk sebagai sumber pembiayaan infrastruktur di Indonesia. Dengan adanya sukuk ini diharapkan menjadi alternatif pembiayaan dalam mengatasi kurangnya dana anggaran dalam pembangunan infrastruktur.

\section{Tinjauan Pustaka}

\section{a. Infrastruktur}

Infrastruktur adalah layanan publik termasuk transportasi, energi, air, kesehatan dan lainnnya yang ditujukan untuk menunjang kegiatan ekonomi dan social. ${ }^{6}$ Jadi Pembangunan infrastruktur ialah suatu langkah atau usaha pertumbuhan dan perubahan yang terencana untuk membangun prasarana atau segala sesuatu yang merupakan penunjang utama terselenggaranya suatu pembangunan. ${ }^{7}$

\section{b. Sukuk}

Sukuk berasal dari kata 'Sakk', berarti dalam peristilahan ekonomi sebagai legal instrument, deed, atau check. jadi, sukuk dapat diartikan sebagai suatu dokumen sah yang menjadi bukti penyertaan modal

5 Fadian, "Analisis Peran Sukuk Bagi Pembangunan Infrastruktur Di Indonesia."

6 Fauziah and Nurwahidin, "Pembiayaan Infrastruktur Dengan Sukuk Negara Di Indonesia: Prosedur Dan Struktur."

${ }^{7}$ Saputri, "Analisis Terhadap Pendapat Imam Syafi'i Tentang Penggunaan Investasi Dana Haji Untuk Pembangunan Infrastruktur." 
atau bukti utang terhadap pemilik suatu harta yang boleh dipindahmilikan dan bersifat jangka panjang. ${ }^{8}$

Dalam standar syariah nomor 17 tahun 2019, AAOIFI (The Accounting and Auditing Organisation of Islamic Financial Institution) dijelaskan bahwa sukuk adalah sertifikat bernilai sama yang mewakili bukti kepemilikan yang tidak terpisahkan atas suatu aset, hak, manfaat, jasa-jasa, atau kepemilikan atas proyek atau aktifitas investasi tertentu. "Sukuk (plural of Sak) are certificates of equal value representing undivided shares in ownership of tangible assets, usufruct and services or (in ownership of) the assets of particular projects or special investment activity. However, this is true after receipt of the value of sukuk, closing of subcriptionand employment of funds received for the purpose for which the Sukuk were issued". ${ }^{9}$

Definisi sukuk sesuai dengan DSN-MUI (Dewan Syariah Nasional Majelis Ulama Indonesia) tertuang dalam fatwa Nomor 32/DSN-MUI/IX/2002 tentang Obligasi Syariah. "Obligasi Syariah adalah suatu surat berharga jangka panjang berdasarkan prinsip syariah yang dikeluarkan Emiten kepada pemegang Obligasi Syariah yang mewajibkan Emiten untuk membayar pendapatan kepada pemegang Obligasi Syariah berupa bagi hasil/margin/fee serta membayar kembali dana obligasi pada saat jatuh tempo".10

${ }^{8}$ Achyar, "Sukuk: Instrumen Pembiayaan Islami Potensial."

9 Fauziah and Nurwahidin, "Pembiayaan Infrastruktur Dengan Sukuk Negara Di Indonesia: Prosedur Dan Struktur."

10 Abubakar and Handayani, "Kesiapan Infrastruktur Hukum Dalam Penerbitan Sukuk (Surat Berharga Syariah) Sebagai Instrumen Pembiayaan Dan Investasi Untuk Mendorong Pertumbuhan Pasar Modal Syariah Indonesia." 
c. Karakteristik Sukuk

1) Terbebas dari unsur riba, gharar dan maysir

2) Sukuk Merupakan bukti kepemilikan suatu aset berwujud atau hak manfaat (beneficial title)

3) Penerbitannya melalui special purpose vehicle (SPV)

4) Memerlukan underlying asset

5) Penggunaan proceeds harus sesuai prinsip syariah

6) Pendapatan berupa imbalan (kupon), marjin, dan bagi hasil, sesuai jenis akad yang digunakan. ${ }^{11}$

\section{d. Keuntungan Investasi Sukuk}

1) Tingkat imbalan tetap

2) Tingkat imbalan kompetitif, lebih tinggi dari rata-rata tingkat bunga deposito bank BUMN

3) Imbalan dibayar tiap bulan

4) Pokok dan imbalan dijamin oleh negara

5) Mendukung pembiayaan pembangunan nasional

6) Cukup dengan 1 juta anda sudah bisa berinvestasi di sukuk

7) Dapat diperdagangkan dipasar sekunder antar investor domestik

8) Akses investasi sesuai prinsip syariah ${ }^{12}$

\section{B. METODE PENELITIAN}

Penelitian menggunakan metode kualitatif dan data sekunder yang digunakan berasal literatur berupa hasil penelitian sebelumnya, dokumen dari lembaga atau instasi yang

${ }^{11}$ Adi, "Analisis Surat Berharga Syariah Negara (SBSN)/Sukuk Dalam Upaya Mendukung Skema Pembiayaan Infrastruktur Di Indonesia."

${ }^{12}$ (Kementerian Keuangan 2020) 
valid, news, serta sumber lain yang mendukung. Data yang di dapat kemudian di analisis secara deskriptif untuk mengambarkan hasil penelitian.

\section{HASIL DAN PEMBAHASAN}

Tujuan diterbitkannya Sukuk Ritel ialah untuk membiayai APBN dan membiayai pembangunan proyek infrastruktur di Indonesia. Penerbitan sukuk pertama kali dilakukan pada tahun 2009,13 Sudah 10 tahun lebih sukuk dalam pembangunan proyek negara memiliki peran penting. Banyak pembangunan proyek yang telah didanai dari sukuk. Sampai saat ini, pemerintah masih menerbitkan sukuk ${ }^{14}$. Berikut perkembangan sukuk ritel:

Grafik C. 1 Perkembangan Sukuk Ritel (Triliun Rp)

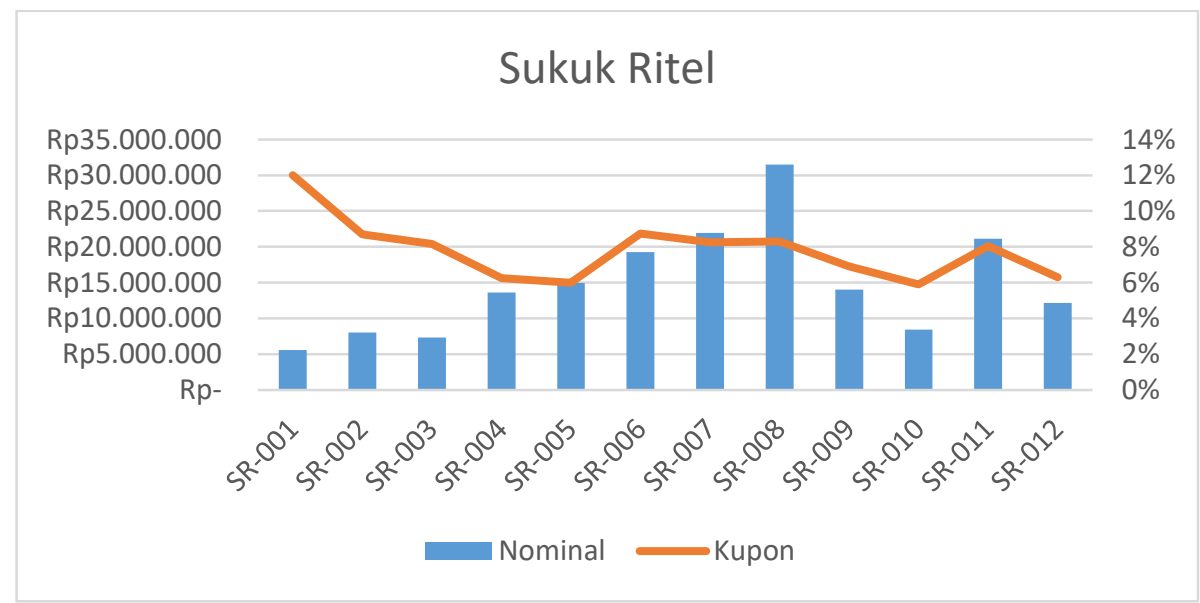

Sumber: Kementerian Keuangan SR 001 - SR 012, Data diolah.

${ }^{13}$ Lamari, Rarasati, and Evita, "An Exploratory Study of Sukuk Utilisation for Transportation Infrastructure Development in Indonesia."

${ }^{14}$ (Kementerian Keuangan 2020) 
Berdasarkan grafik diatas, sukuk pertama diterbitkan pada tahun 2009 yaitu SR-001 dengan tingkat imbalan 12,00\% memperoleh dana sebesar Rp. 5.56 triliun menggunakan akad ijarah sale and lease back dan tenor 3 tahun. Selanjutnya tahun 2010 pemerintah juga menerbitkan SR-002 dengan tingkat imbalan 8,70\% yang lebih rendah dari SR-001 dan memperoleh dana sebesar Rp. 8 triliun. Dengan tenor 3 tahun.

Tahun berikutnya SR-003 telah diterbitkan oleh pemerintah dan mendapatkan dana sebesar Rp. 7.34 Triliun dimana tingkat imbalan 8,15\%. Selanjutnya tahun 2012, pemerintah menerbitkan SR-004 dengan tingkat imbalan 6,25\% dibandingkan dengan SR-003 mengalami penurunanan yang drastis, tetapi pemerintah memperoleh dana sebesar Rp. 13.60 triliun. berikutnya tahun 2013 diterbitkan SR-005 memperoleh dana sebesar Rp. 14.97 triliun dimana tingkat imbalan sebesar $6,00 \%$.

Tahun 2014, SR-006 telah diterbitkan oleh pemerintah dimana tingkat imbalan 8,75\% sehingga mendapatkan dana sebesar Rp. 19.23 triliun. Selanjutnya tahun 2015 pemerintah menerbitkan SR-007 dimana tingkat imbalan 8,29\% dan memperoleh dana sebesar Rp. 21.96 triliun.

Tahun 2016, pemerintah menerbitkan sukuk SR-008 dengan memperoleh dana sebesar RP. 31.5 triliun dimana perolehan tahun ini lebih tinggi dibandingkan dengan perolehan tahun sebelumnya, dengan tingkat imbalan 8,30\%. Selanjutnya tahun 2017 pemerintah menerbitkan sukuk SR-009 dengan tingkat imbalan 6,90\% sehingga mendapatkan dana sebesar Rp. 14 triliun mengalami penurunan jika dibandingkan SR-008. Tahun berikutnya pemerintah memperoleh dana juga menurun sebesar Rp. 8.43 triliun dengan mengeluarkan sukuk SR-010 dengan tingkat imbalan sebesar 5,90\%.

Tahun 2019 pemerintah mampu memperoleh dana sebesar Rp. 21.11 triliun mengalami kenaikan dibandingkan tahun sebelumnya yaitu dengan meluncurkan SR-011 dengan 
J-Al-Mutharahah : Vol. 17 No. 1 Januari-Juni 2020

tingkat imbalan sebesar 8,50\%. Dan selanjutnya tahun 2020 diterbitkan sukuk SR-012 pemerintah hanya memperoleh Rp. 12.14 Triliun dengan tingkat imbalan 6,30\%.

Tabel C. 1 Rincian Penerbitan SR 012

\begin{tabular}{ll}
\hline Akad & Ijarah Asset to be Leased \\
\hline Underlying Asset & $\begin{array}{l}\text { Barang Milik Negara dan Proyek APBN } \\
\text { Tahun 2020 }\end{array}$ \\
\hline $\begin{array}{l}\text { Masa Penawaran } \\
\text { Penerbitan/stelmen }\end{array}$ & 24 Februari 2020 - 18 Maret 2020 \\
\hline Tanggal Jatuh Tempo & $\begin{array}{l}\text { 10 Maret 2023 (tenor 3 tahun, bullet } \\
\text { payment) }\end{array}$ \\
\hline Tingkat Imbalan/Kupon & 6,30\% per tahun \\
\hline Pembayaran Imbalan & $\begin{array}{l}\text { Dibayarkan bulanan (pada tanggal 10 } \\
\text { setiap bulan) }\end{array}$ \\
\hline Minimum Pemesanan & Rp1.000.000,- (satu juta rupiah) \\
\hline Maksimum Pemesanan & Rp3.000.000.000,- (tiga miliar rupiah) \\
\hline $\begin{array}{l}\text { Bentuk dan karakteristik } \\
\text { Sukuk Negara }\end{array}$ & $\begin{array}{l}\text { Tanpa Warkat, dapat diperdagangkan } \\
\text { (tradale) }\end{array}$ \\
\hline Penerbit & $\begin{array}{l}\text { Pemerintah melalui } \\
\text { Penerbit SBSN Indonesia }\end{array}$ \\
\hline $\begin{array}{l}\text { Pembayaran } \\
\text { Pertama }\end{array}$ & 10 April 2020 \\
\hline
\end{tabular}

Sumber: Siaran Pers DJPPR Kementerian Keuangan

Kementerian keuangan menunjuk mitra penjualan untuk menawarkan serta memesan sukuk Bagi masyarakat yang ingin berinvestasi 15. Mitra Penjualan SR-012 Berjumlah 28 mitra penjualan. Yaitu Bank Centra l Asia, Bank Mandiri, Bank Negara Indonesia, Bank Permata, Bank Rakyat Indonesia, Bank

15 Pratiwi, Mainata, and Ramadayanti, "Peran Sukuk Negara Dalam Pembiayaan Infrastruktur." 
Tabungan Negara, Bank CIMB Niaga,Bank Danamon Indonesia, Bank Maybank Indonesia, Bank Panin, Bank DBS Indonesia, Bank OCBC NISP, Bank HSBC Indonesia, Bank Commonwealth, Bank UOB Indonesia, Bank Muamalat Indonesia, Bank Syariah Mandiri, Bank BRISyariah, Trimegah Sekuritas Indonesia, Danareksa Sekuritas, Bahana Sekuritas, Mandiri sekuritas, Sinarmas Sekuritas, Bareksa Portal Investasi, Star Mercato Capitale (Tanamduit), Nusantara Sejehtera Investama (Invisee), Investree Radhika Jaya, Mitrausaha Indonesia Grup (Modalku).

Pembangunan adalah sikap berkelanjutan pemerintah dari pemanfaatan dana sukuk seperti tahun-tahun sebelumnya. Yang bertujuan untuk meningkatkan kesejahteraan rakyat. Setiap tahun, APBN telah dirancang pemerintah untuk masa satu tahun berjalan. APBN tidak hanya berasal dari pendapatan negara saj melainkan juga dari penjualan obligasi dan sukuk. ${ }^{16}$ Berikut penjelasan mengenai pertumbuhan dan perkembangan infrastruktur diindonesia:

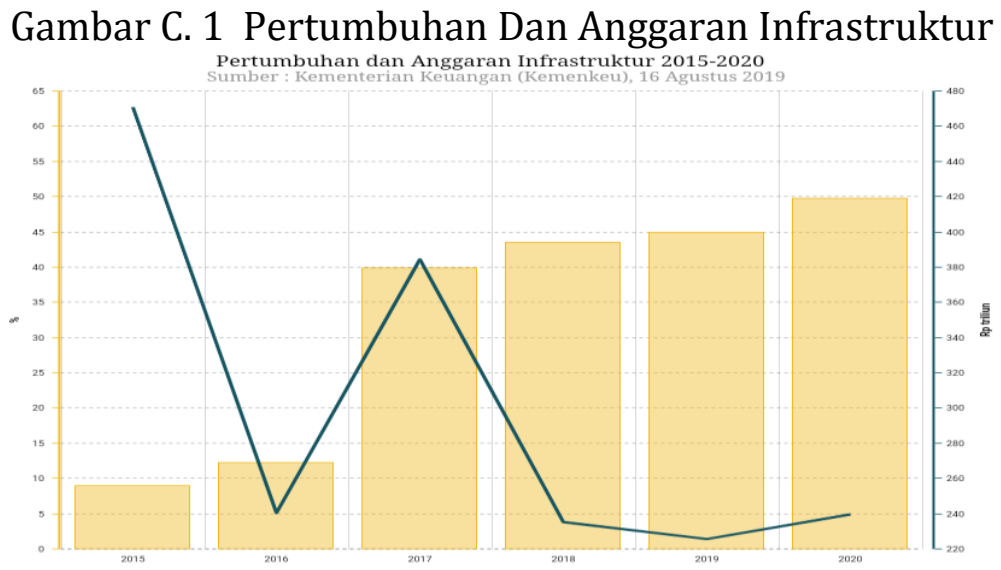

D katadata

Sumber : Kementerian Keuangan

16 Fitrianto, "Sukuk Instrumen Pembiayaan Pemerintah Untuk Pembangunan Negara." 
Dari gambar diatas Alokasi anggaran infrastruktur dalam APBN mengalami peningkatan dari tahun ke tahun. Dan untuk mengadakan pembangunan infrastruktur juga memerlukan biaya yang tidak sedikit. Hal ini merupakan langkah pemerintah untuk meningkatkan infrastruktur diindonesia.

Pemerintah telah menggelontorkan dana yang cukup besar dalam pembangunan infrastruktur. Sejak terpilih menjadi presiden RI tahun 2014, presiden Joko Widodo memberi perhatian serius terhadap pembanguan infrastruktur. Anggaran pembangunan infrastruktur langung dinaikkan menjadi $62,7 \%$ sebesar Rp 256,1 Triliun pada tahun 2015. Selanjutnya pada tahun 2017, anggaran infrastruktur kembali dinaikkan hingga 41,1\% menjadi Rp. 379.4 Triliun, setelah pada tahun 2016 anggaran hanya naik 5,1\%. Pada tahun ini 2020 anggaran infrastruktur mendapat alokasi sebesar Rp. 419,2 Triliun atau meningkat 4,9\% dibandingkan tahun sebelumnya hanya sebesar Rp. 399,7 Triliun. Sasaran target dalam anggaran infrastruktur APBN 2020 adalah ${ }^{17}$ :

1. Pembangunan Bendungan 49 unit

2. Pembangunan konektivitas $486 \mathrm{~km}$

3. Pembangunan/Penyelesaian Rel Kereta Api (238.8 km'sp)

4. Pembangunan dan Rehabilitasi Jembatan (19.014 m)

5. Pembangunan Bandara Baru 3 unit

6. Pembangunan perumahan untuk MBR 5,348 unit dan Rumah Khusus 2.000 unit.

Peran sukuk dalam APBN tidak dapat dilepaskan, karena sudah sangat jelas disebutkan dalam Undang - Undang Nomor 19 Tahun 2008 tentang SBSN bahwa sukuk mempunyai kontribusi dalam pembangunan proyek negara Sehingga peran sukuk sebagai Surat Berharga Syariah Negara, mempunyai peran yang

${ }^{17}$ Kementerian keuangan, “APBN 2020." 
sangat penting di dalam kontribusi pembangunan negara yang berkelanjutan. ${ }^{18}$ Peran sukuk dalam negara adalah: ${ }^{19}$

1. Menyediakan alternatif sumber pembiayaan APBN

2. Menyediakan instrumen investasi dan likuiditas berbasis syariah

3. Mengembangkan pasar keuangan syariah

4. Menyediakan benchmark bagi penerbitan sukuk korporasi.

Berikut proyek-proyek yang akan dibiayai menggunakan sukuk negara pada tahun 2020 dengan anggaran sebesar Rp 27,35 Triliun sebanyak 728 proyek yang tersebar di 34 provinsi ${ }^{20}$, sebagai berikut:

Tabel C. 2. Proyek yang akan dibiayai sukuk tahun 2020

\begin{tabular}{|c|c|c|c|}
\hline No & Proyek & Kementerian & Nominal \\
\hline \multirow[t]{2}{*}{1.} & Infrastruktur & Kementerian & $\mathrm{Rp} \quad 6,90$ \\
\hline & Transportasi & Perhubungan & Triliun \\
\hline \multirow[t]{3}{*}{2.} & 171 Infrastruktur Jalan & DitJen & $\mathrm{Rp} \quad 10,60$ \\
\hline & Dan Jembatan & Kemen & triliun \\
\hline & & PUPR & \\
\hline \multirow[t]{7}{*}{3.} & Infrastruktur & Ditjen & 4,50 \\
\hline & Pengendalian & Kemen PUPR & triliun \\
\hline & Dan Lahar, Pengelolaan & & \\
\hline & Bendungan & & \\
\hline & Embung, & & \\
\hline & Pengelolaan & & \\
\hline & Utama Perkotaan & & \\
\hline \multirow[t]{3}{*}{4.} & 10 Embarkasi Haji Dan & Ditjen & 460 \\
\hline & 40 Pusat Pelayanan Haji & Kemenag & miliar \\
\hline & Terpadu & & \\
\hline
\end{tabular}

\footnotetext{
${ }^{18}$ Fitrianto, "Sukuk Instrumen Pembiayaan Pemerintah Untuk Pembangunan Negara."

${ }^{19}$ Kementerian Keuangan, "Investasi Syariah Melalui Surat Berharga Syariah Negara ( Sukuk Negara )."

${ }^{20}$ Kementerian Keuangan, "Ini Proyek-Proyek SBSN 2020."
} 
J-Al-Mutharahah : Vol. 17 No. 1 Januari-Juni 2020

\begin{tabular}{|c|c|c|c|}
\hline No & Proyek & Kementerian & inal \\
\hline 5. & $\begin{array}{l}\text { Pembangunan Sarana } \\
\text { Dan Fasilitas Gedung } \\
\text { PTKIN Dan } 136 \\
\text { Madrasah }\end{array}$ & $\begin{array}{l}\text { Ditjen } \\
\text { Pendidikan } \\
\text { Islam Kemenag }\end{array}$ & $\begin{array}{l}\mathrm{Rp} \\
\text { triliun }\end{array}$ \\
\hline 6. & $\begin{array}{l}228 \text { Pembangunan Dan } \\
\text { Rehabilitasi Gedung } \\
\text { Balai Nikah Dan } \\
\text { Manasik Haji Di Senilai }\end{array}$ & $\begin{array}{l}\text { Ditjen Bimas } \\
\text { Islam Kemenag }\end{array}$ & $\begin{array}{l}\mathrm{Rp} 356,25 \\
\text { miliar }\end{array}$ \\
\hline 7. & $\begin{array}{lr}6 \text { Pembangunan Pusat } \\
\text { Konservasi, } \\
\text { Pembangunan Sekolah } \\
\text { Menengah Kehutanan } \\
\text { Negeri Dan } \\
\text { Pembangunan } \\
\text { Laboratorium }\end{array}$ & Ken & $\begin{array}{l}\text { Rp 237,41 } \\
\text { miliar }\end{array}$ \\
\hline 8. & $\begin{array}{lr}24 & \text { Pembangunan } \\
\text { Gedung } & \text { Perguruan } \\
\text { Tinggi } & \end{array}$ & $\begin{array}{l}\text { Kemen } \\
\text { Ristekdikti }\end{array}$ & $\begin{array}{l}\mathrm{Rp}_{\text {triliun }} \\
\text { 1,49 }\end{array}$ \\
\hline 9. & $\begin{array}{l}1 \text { Pengembangan } \\
\text { Laboratorium }\end{array}$ & BSN & $\begin{array}{l}\mathrm{Rp} \\
\text { miliar }\end{array}$ \\
\hline 10. & $\begin{array}{l}4 \quad \text { Pembangunan } \\
\text { Laboratorium }\end{array}$ & LIPI & $\begin{array}{l}\text { Rp } 500 \\
\text { miliar }\end{array}$ \\
\hline 11. & $\begin{array}{lr}1 & \text { Laboratorium } \\
\text { Pengujian } & \text { Komponen } \\
\text { Peseta } & \\
\end{array}$ & LAPAN & $\begin{array}{l}\text { Rp } 125 \\
\text { miliar }\end{array}$ \\
\hline
\end{tabular}

Sumber: Kementerian Keuangan

Adapun beberapa proyek pembangunan infrastruktur negara yang telah didanai dengan sukuk negara adalah sebagai berikut ${ }^{21}$ :

${ }^{21}$ (Kementerian Keuangan 2020) 
J-Al-Mutharahah : Vol. 17 No. 1 Januari-Juni 2020

1. Pembangunan Jalur Kereta Double Track Selatan Jawa Cirebon-Kroya-Solo-Madiun-Jombang (Sukuk Negara 2013-2019).

2. Pembangunan Tol Solo - Ngawi Seksi I - Colomadu Karanganyar Jawa Tengah (Sukuk Negara 2017-2018)

3. Pembangunan Gedung Perkuliahan UIN Manado Sulawesi Utara (Sukuk Negara 2018)

4. Pembangunan Jembatan Pulau Balang Samarinda Kalimantan Timur (Sukuk Negara 2015-2018)

5. Pembangunan Gedung Perkuliahan IAIN Salatiga Jawa Tengah (Sukuk Negara 2015-2016)

6. Pembangunan Ramp On/Off Flyover Amplas Medan (Sukuk Negara 2016)

Selain dari proyek diatas yang disebutkan, proyek yang telah dibiayai oleh sukuk masih banyak yang tidak mungkin semuanya disebutkan. Dengan diterbitkannya Surat Berharga Syariah Nasional sejak tahun 2008 pemerintah ingin mendorong perkembangan keuangan syariah diindonesia. Setelah 10 tahun SBSN diterbitkan telah turut berperan langsung dalam pembangunan infrastruktur di Indonesia dan juga menjadi instrumen pembiayaan dan investasi syariah yang berkembang.

\section{KESIMPULAN}

SBSN diterbitkan dengan tujuan untuk membiayai APBN termasuk membiayai pembangunan infrastruktur. Sukuk menjadi komponen penting dalam APBN untuk membiayai proyek negara. Dikarenakan Sukuk menggunakan prinsipprinsip yang sesuai dengan syariah sehingga terhindar dari halhal yang diharamkan syariah. Seperti mengandung unsur riba, gharar, maisir dan lain- lain. Sejak diterbitkan hingga tanggal 13 Februari 2020, Akumulasi hasil penerbitan SBSN mencapai Rp. 1.253,4 T. Hasil penerbitan Sukuk tersebut digunakan pemerintah untuk mendanai berbagai proyek pembangunan infrastruktur di indonesia. Pemerintah bisa memaksimalkan 
potensi sukuk sebagai alternatif pembiayaan infrastruktur dan mulai mengurangi ketergantungan pada hutang luar negeri dalam pembiayaan infrastruktur.

Saran yang dapat diberikan untuk pengembangan pembiayaan infrastruktur dengan sukuk terutama untuk pemerintah sebagai penerbit sukuk, yakni terkait pemasaran, masih banyak masyarakat belum mengetahui mengenai sukuk seharusnya pemasaran dibuat lebih menarik dan inovatif sehingga banyak diketahui oleh masyarakat luas. Untuk mencapai hal tersebut, strategi yang dapat digunakan bisa melalui kerjasama antar lembaga, pengoptimalan penggunaan TI, dan inovasi.

\section{REFERENSI}

Abubakar, Lastuti, and Tri Handayani. 2017. "Kesiapan Infrastruktur Hukum Dalam Penerbitan Sukuk (Surat Berharga Syariah) Sebagai Instrumen Pembiayaan Dan Investasi Untuk Mendorong Pertumbuhan Pasar Modal Syariah Indonesia." Jurnal Jurisprudence 7(1): 1-14.

Achyar, Munir. 2018. "Sukuk: Instrumen Pembiayaan Islami

Potensial." LABATILA : Jurnal Ilmu Ekonomi Islam 2(1):1940.

Adi, Yuli Prasetya. 2016. "Analisis Surat Berharga Syariah Negara (SBSN)/Sukuk Dalam Upaya Mendukung Skema Pembiayaan Infrastruktur Di Indonesia." Tangerang

Selatan: Politeknik Keuangan Negara STAN. Skripsi.

Anik, Anik, and Iin Emy Prastiwi. 2017. "Pengembangan

Instrumen Sukuk Dalam Medukung Pembangunan Infratruktur." Jurnal Ilmiah Ekonomi Islam 3(03):173-80. Ardi, Muhammad. 2018. "Pengaruh Sukuk Terhadap Pertumbuhan Ekonomi Indonesia." Iqtishaduna 9(1):8597.

Beik, Irfan Syauqi. 2011. "Memperkuat Peran Sukuk Negara Dalam Pembangunan Ekonomi Indonesia." Jurnal Ekonomi 
J-Al-Mutharahah : Vol. 17 No. 1 Januari-Juni 2020

Islam Al-Infaq 2(2): 65-72.

Datuk, Bahril. 2014. "Sukuk, Dimensi Baru Pembiayaan Pemerintah Untuk Pertumbuhan Ekonomi." Jurnal Riset Akuntansi \& Bisnis 14(1): 111-24.

Fadian, Baiti Nur. 2017. "Analisis Peran Sukuk Bagi Pembangunan Infrastruktur Di Indonesia." PROSIDING Seminar Nasional Dan Call for Papers "Tantangan Pengembangan Ilmu Akuntansi, Inklusi Keuangan, Dan Kontribusinya Terhadap Pembangunan Ekonomi Berkelanjutan" 1-13.

Fauziah, Syifa, and Nurwahidin. 2020. "Pembiayaan Infrastruktur Dengan Sukuk Negara Di Indonesia: Prosedur Dan Struktur." JIMEA / Jurnal Ilmiah MEA (Manajemen, Ekonomi, Dan Akuntansi) 4(1): 30-42.

Fitrianto. 2019. "Sukuk Instrumen Pembiayaan Pemerintah Untuk Pembangunan Negara." At-Taradhi: Jurnal Studi Ekonomi 10(1): 71-87.

Helmi, Achmad. 2015. "Komparasi Pembiayan Pembangunan Infrastruktur Pemerintah Dengan Dana Obligasi Konvensional Dan Obligasi Syariah / Sukuk (Studi Kasus Pembangunan Jalan Tol Trans Sumatera)." Yogyakarta: UIN Sunan Kalijaga. Tesis.

Kementerian keuangan. 2020. “APBN 2020." Retrieved (https://www.kemenkeu.go.id/apbn2020).

Kementerian Keuangan. 2017. "Investasi Syariah Melalui Surat Berharga Syariah Negara ( Sukuk Negara)."

Kementerian Keuangan. 2020. "Ini Proyek-Proyek SBSN 2020.” Retrieved

(https://www.kemenkeu.go.id/publikasi/berita/iniproyek-proyek-sbsn-2020/).

Keuangan, Kementerian. 2020. "Sukuk Ritel." Retrieved (https://www.kemenkeu.go.id/sukukritel).

Khatimah, Husnul. 2017. "Sukuk Dan Kontribusinya Dalam Pembiayaan Pembangunan." Optimal: Jurnal Ekonomi Dan 
J-Al-Mutharahah : Vol. 17 No. 1 Januari-Juni 2020

Kewirausahaan 11(1): 83-103.

Lamari, Fiona, Ayomi Dita Rarasati, and Meilia Evita. 2018. “An Exploratory Study of Sukuk Utilisation for Transportation Infrastructure Development in Indonesia." Makara Journal of Technology 22(1): 53-59.

Pratiwi, Angrum, Dedy Mainata, and Rizky Suci Ramadayanti. 2017. "Peran Sukuk Negara Dalam Pembiayaan Infrastruktur." Al-Tijary 2(2): 155-76.

Saputri, Resky Mertarega. 2019. “Analisis Terhadap Pendapat Imam Syafi'i Tentang Penggunaan Investasi Dana Haji Untuk Pembangunan Infrastruktur." Lampung: Universitas Islam Negeri Raden Intan. Skripsi.

Siregar, Selamat. 2017. "Hubungan Investasi Dengan PDRB Riil Kota Medan." Jurnal Ekonomi 6(1): 1-8. 